\title{
Ceografial
}

\section{Faktor-faktor penentu harga rumah dari perspektif pemaju perumahan}

\author{
Azima Abdul Manaf ${ }^{1}$, Goh Ie Zheng ${ }^{1}$ \\ ${ }^{1}$ Program Sains Pembangunan, Pusat Pembangunan, Sosial dan Persekitaran, \\ Fakulti Sains Sosial dan Kemanusiaan, Universiti Kebangsaan Malaysia \\ Correspondence: Azima Abdul Manaf (email: azima@ukm.edu.my)
}

Received: 15 November 2019; Accepted: 22 November 2019; Published: 25 November 2019

\begin{abstract}
Abstrak
Peningkatan harga rumah telah menjadi isu yang sangat serius di Malaysia. Peningkatan harga yang berterusan telah mengakibatkan ramai dalam kalangan pembeli tidak mampu untuk membeli rumah. Seringkali peningkatan harga ini dikaitkan dengan pengaruh faktor permintaan dan penawaran harga rumah. Pelbagai langkah telah diambil bagi mengekang kenaikan harga rumah dengan tujuan membolehkan pembeli memiliki rumah. Namun kenaikan harga seolaholah tidak mampu dibendung. Persoalannya apakah faktor yang menjadi penentu perletakan harga rumah oleh pihak pemaju? Oleh itu, tujuan artikel ini adalah untuk membincangkan faktor penentu yang digunakan oleh pihak pemaju dalam meletakkan harga rumah oleh syarikat pembinaan mereka. Sehubungan itu soal selidik telah diedarkan dalam kalangan 76 pemaju projek pembinaan di kawasan kajian. Maklumbalas daripada pemaju telah dianalisis menggunakan analisis deskriptif dengan menggunapakai skor min bagi setiap faktor. Tujuannya adalah untuk mengenalpasti faktor yang menjadi penentu kepada peletakan harga sesebuah unit kediaman oleh pihak pemaju. Faktor perletakan harga oleh pemaju perumahan telah dibahagikan kepada dua faktor utama iaitu faktor dalaman dan faktor luaran. Analisis dapatan kajian mendapati terdapat beberapa faktor yang menjadi faktor penentu perletakan harga rumah oleh pemaju di kawasan kajian. Bagi faktor dalaman, faktor jarak atau lokasi, persekitaran sosial, rekabentuk struktur rumah, spekulasi, status fizikal dan faktor keselamatan merupakan antara faktor yang digunakan oleh pemaju dalam menentukan harga sebuah unit yang dibina. Manakala bagi faktor luaran, didapati kadar pinjaman, penggunaan teknologi hijau, penggunaan mesra alam serta cukai perumahan telah mempengaruhi penentuan perletakan harga oleh pemaju. Bagi menangani masalah kenaikan harga yang berterusan, pelbagai langkah yang berkait dengan keperluan dan kemampuan pengguna perlu diambilkira dalam projek pembinaan perumahan.
\end{abstract}

Kata kunci: faktor dalaman, faktor luaran, harga rumah, pemaju, perspektif pemaju perumahan 


\title{
Factors determining the house prices from the housing developers' perspectives
}

\begin{abstract}
The increase in housing prices has become a serious issue in Malaysia. The continuous increase in house prices has resulted in many home buyers being unable to buy the house. Often the rise in prices is attributed to the influence of demand factor and house price offerings. Various measures have been taken to curb the price hike for the purpose of enabling the buyer to own a home. However, the price increase seems to be uncontained. The question is what factors determine the price of a house for a developer? In this regard, the purpose of this article is to discuss the determinant factors used by developers in determining the house price under construction by their company. Accordingly, the questionnaire was distributed among the 76 construction project developers in the study area. The developers' responses were analysed using the descriptive analysis using mean scores to identify the key factors which determine the pricing of a residential unit by the developer. The findings of the study indicate that there are several factors that determine the home prices by the developers in the study area. The pricing determinant factor by the developer can be divided into two main factors, namely the internal and external factors. The internal factors are influenced by distance or location factors, social environment, house structure design, speculation, physical status and safety factors. Whereas for external factors, it appears that lending rates, green technology use, eco-friendly use, and housing taxes have influenced the price determinant by the developers. To address the problem of ongoing price hikes, various steps related to consumer needs and capabilities need to be considered in a housing construction project.
\end{abstract}

Keywords: internal factors, external factors, house prices, developers, developer's perspectives.

\section{Pengenalan}

Pasaran harta kediaman di Malaysia telah mengalami peningkatan harga yang sangat drastik sejak lima belas tahun yang lalu (Husain et al., 2011). Peningkatan itu berlaku di beberapa negeri di Malaysia dengan kadar kenaikan harga yang sangat tinggi. Hal ini jelas apabila harga rumah didapati terus meningkat sehingga menjadikannya tidak dapat atau tidak mampu dibeli oleh pembeli (Abraham \& Hendershoti, 2014). Keadaan ini didapati berkait rapat senario jangkaan dan balikan keuntungan daripada sesuatu projek pembinaan.

Pada tahun 2017, didapati harga purata untuk semua rumah di Malaysia berada pada RM409,899. Kuala Lumpur masih mencatatkan harga tertinggi pada RM798,011dan Selangor menduduki tempat kedua pada RM469,518 dan diikuti oleh Sabah, Pulau Pinang dan Sarawak masing-masing pada harga RM430,767, RM429,234 dan RM428,801 (Laporan Pasaran Harta, 2018). Peningkatan harga rumah yang berterusan sudah pasti membataskan kemampuan membeli dalam kalangan pembeli rumah. Namun senario peningkatan harga rumah bukan sahaja dihadapi oleh Malaysia tetapi dihadapi juga beberapa negara yang lain. Sebagai contoh harga perumahan untuk pemilikan rumah di Amerika Syarikat telah mengalami peningkatan yang sangat drastik iaitu sebanyak 105\% (Engle, Lilien \& Watson, 1985). Manakala di Rusia pula, 
harga perumahan juga mengalami peningkatan yang drastik sehingga menjadikannya sangat mahal untuk dibeli oleh pembeli rumah (Mints, 2008).

Malaysia telah memperkenalkan banyak langkah dalam usaha mengurangkan kenaikan harga rumah. Antaranya, kerajaan Malaysia telah memperkenalkan cukai SST iaitu Sales Service Tax di mana 10 peratus yang akan dikenakan adalah hanya membayar sekali sahaja yang cuma melibatkan pengeluar, kontraktor dan pembekal. Tambahan itu, pengecualian terhadap bahan pembinaan terutamanya simen, batu bata dan lain-lain lagi juga tidak akan dikenakan SST. Dengan mengecualikan bahan pembinaan rumah, harga rumah dijangka akan turun antara 5 hingga 10 peratus (Rizanizam, 2018). Tindakan serius daripada kerajaan jelas apabila bagi pemaju yang tidak mahu menurunkan harga rumah, pihak kerajaan akan mengambil tindakan dengan menolak balik langkah pengecualian Cukai Jualan dan Perkhidmatan (SST) sebanyak enam peratus yang dikenakan terhadap perkhidmatan dan bahan binaan (Rahimah, 2018). Selain itu, kerajaan juga ada menyediakan rumah sejahtera dan rumah mampu milik kepada rakyat yang berkelayakan seperti Program Perumahan Rakyat (PPR) dan Perumahan Rakyat 1 Malaysia (PR1MA). Namun, usaha ini belum boleh mengatasi masalah yang berkait dengan harga rumah yang tinggi terutamanya bagi generasi muda. Walaupun pelbagai langkah sudah diambil oleh pihak kerajaan, namun ini masih tidak memadai untuk menangani masalah kenaikan harga rumah. Oleh itu, artikel ini telah mendapatkan pandangan pemaju berhubung dengan faktorfaktor penentu yang dipertimbangkan oleh mereka dalam menentukan harga rumah bagi sesuatu projek pembinaan untuk kediaman.

\section{Kajian lepas}

Penelitian oleh pengkaji pasaran perumahan lebih cenderung melihat isu harga rumah dalam konteks faktor-faktor yang mempengaruhi kenaikan harga rumah. Kajian oleh Auyong et al. (2018), tentang kedinamikan harga perumahan mendapati bahawa spekulator, permintaan terhadap perumahan, kos tanah, kos bahan pembinaan, kos pematuhan dan ciri-ciri rumah akan mempengaruhi harga rumah. Sebaliknya, responden bersetuju bahawa kadar gadai janji yang tinggi bukanlah faktor yang mempengaruhi harga perumahan. Dapatan lain juga mendedahkan bahawa terdapat hubungan songsang antara dasar pembiayaan dengan harga perumahan. Semua responden berpendapat bahawa tidak wujudnya gelembung perumahan iaitu house bubble, dan harga perumahan menurun lagi terutamanya bagi perumahan berkos sederhana, dan kebanyakan pembeli rumah merupakan pembeli yang pertama kali membeli rumah.

Kok, Ismail dan Lee (2018) dalam kajian tentang sumber perubahan harga rumah di Malaysia mendapati wujud kesan KDNK sebenar terhadap harga rumah. Selain itu, transaksi juga didapati telah memberikan pengaruh yang kuat terhadap harga rumah. Hal ini jelas apabila analisis mendapati transaksi secara signifikannya memberi kesan terhadap harga rumah. Walau bagaimanapun kadar faedah didapati mempunyai kesan yang sangat sedikit terhadap perubahan harga. Ini kerana dalam jangkamasa pendek kadar faedah didapati tidak banyak memberikan pengaruhnya terhadap harga berbanding dengan transaksi yang didapati telah memainkan peranannya dalam mempengaruhi harga rumah.

Ferlan, Bastic dan Psunder (2017) mengkaji tentang faktor yang mempengaruhi harga pasaran perumahan mendapati jarak dan lokasi dari pusat bandar memberikan pengaruh yang sangat penting terhadap nilai harga rumah. Faktor seperti penyediaan tempat ruang letak kereta juga didapati merupakan salah satu faktor yang mempunyai kesan yang besar terhadap nilai 
harga perumahan. Selain itu, faktor persekitaran seperti bunyi bising serta status fizikal perumahan juga boleh mempengaruhi harga rumah. Hasil kajian mereka juga mendapati bahawa majoriti responden berpendapat bahawa kewujudan lif dalam bangunan yang tinggi boleh juga meningkatkan nilai harga kediaman

Kamal, Hassan dan Osmadi (2016) dalam kajian tentang faktor mempengaruhi harga perumahan mendapati bahawa lokasi adalah faktor yang paling mempengaruhi harga perumahan. Ini adalah kerana apabila lokasi projek itu dilengkapi dengan infrastruktur yang sesuai, spesifikasi reka bentuk yang berkualiti tinggi dan baik, lokasi itu boleh menyumbang kepada penetapan harga rumah. Faktor kedua yang mempengaruhi harga perumahan adalah faktor makroekonomi. Kadar inflasi juga didapati akan mempengaruhi harga perumahan. Pada masa yang sama, pemaju berpendapat bahawa apabila kadar faedah rendah dan orang ramai lebih cenderung untuk membeli rumah. Situasi ini akan mewujudkan permintaan yang tinggi terhadap perumahan dan secara automatiknya akan mempengaruhi keputusan pemaju dalam penetapan harga rumah. Faktor ketiga yang mempengaruhi harga perumahan adalah faktor demografi. Pertumbuhan populasi, taraf hidup dan gaya hidup semasa telah menyumbang kepada keputusan pemaju dalam menentukan harga perumahan. Faktor seterusnya adalah berkait dengan adalah isu tanah dan zon. Dapatan kajian menunjukkan bahawa status tanah sama ada pegangan bebas atau pegangan secara pajakan juga boleh mempengaruhi keputusan pemaju mengenai harga rumah. Pemaju menetapkan harga yang lebih tinggi ke atas pegangan bebas berbanding dengan tanah pajakan. Keperluan untuk pengezonan semula dan penambakan tanah juga dapat mempengaruhi harga perumahan.

Penelitian oleh Osmadi et al. (2015) mengenai elemen harga rumah juga mendapati bahawa harga rumah ditentukan oleh permintaan terhadap rumah yang bukan hanya unit kediaman itu sendiri, tetapi juga oleh faktor lokasi di mana unit itu berada. Terdapat banyak ciri-ciri struktural seperti kejiranan dan lokasi yang boleh memberi impak terhadap elemen harga rumah. Ciri-ciri struktur, faktor lokasi, dan ciri kejiranan boleh menentukan harga pelbagai sub-pasaran. Dalam hal ini sub-pasaran pula ditentukan oleh jenis struktur seperti kediaman seperti rumah teres, rumah bandar dan kondominium. Dapatan kajian menunjukkan bahawa harga perumahan di Malaysia banyak bergantung kepada populasi, permintaan dan bekalan, lokasi, ciri fizikal, kebolehaksesan, kos bahan dan pendapatan. Selain itu, faktor kejiranan juga mempengaruhi pemilihan kawasan kediaman.

Raden (2015) pula mendapati terdapat hubungan antara keutamaan yang dicadangkan oleh pemaju hartanah dengan pilihan kediaman oleh pembeli rumah. Dalam hal ini wujud hubungan yang signifikan dalam hubungan keutamaan pengguna terhadap harga dengan pemilihan terhadap lokasi perumahan, akses terhadap tol memberi kesan langsung terhadap p harga rumah. Selain itu terdapat korelasi positif dan tindak balas positif oleh pembeli dalam faktor persekitaran. Selain itu, beliau juga mendapati terdapat beberapa faktor lain yang mempengaruhi harga iaitu reka bentuk, aksesibiliti, kemudahan dan jenama serta reputasi pemaju.

Selain itu, kajian oleh Sorina (2014) mendapati bahawa terdapat dua pembolehubah makro ekonomi iaitu bilangan permit yang dikeluarkan untuk perumahan dan jumlah kredit yang diberikan untuk perumahan juga boleh memberi pengaruh terhadap harga perumahan. Dapatan kajian juga mendapati bahawa faktor-faktor lain seperti inflasi, kadar faedah dan KDNK secara tidak langsung juga mempengaruhi harga hartanah, yang secara pasti jelasnya akan mempengaruhi jumlah permit. Walau bagaimanapun harga perumahan juga didapati bergantung kepada jumlah penduduk disesebuah kawasan. Peningkatan populasi juga boleh meningkatkan permintaan terhadap rumah. Oleh itu, pemaju akan bertindak dengan meningkatkan harga 
sesuatu perumahan apabila didapati jumlah penawaran kurang berbanding dengan jumlah permintaan rumah.

Liew dan Haron (2013) menyimpulkan bahawa faktor utama yang mempengaruhi kenaikan harga rumah adalah ketidak stabilan dalam pasaran perumahan, peningkatan dalam kos pembinaan perumahan, pertumbuhan penduduk, peningkatkan permintaan terhadap perumahan, keuntungan jangka panjang dalam perumahan, pertumbuhan KDNK, penurunan bekalan perumahan baru, yuran pemindahan dan cukai perumahan serta kualiti perumahan, penampilan rumah dan kekurangan kemudahan awam. Secara keseluruhannya, terdapat banyak faktor yang mempengaruhi harga rumah. Namun masih terdapat lompang kerana kebanyakan penelitian yang dilakukan oleh pengkaji-pengkaji lalu hanya membincangkan isu harga rumah daripada perspektif sebab permintaan terhadap rumah meningkat dalam kalangan pengguna. Dalam hal ini kajian yang menyentuh faktor penentuan harga rumah daripada perspektif pemaju masih belum banyak diterokai oleh pengkaji lampau.

\section{Metodologi}

Kajian ini menggunakan kaedah kuantitatif. Borang soal selidik yang dirangka diedarkan kepada responden yang terdiri daripada pihak pemaju perumahan. Borang soal selidik telah diemailkan kepada pemaju mendapatkan maklumbalas berhubung faktor-faktor yang dipertimbangkan oleh mereka semasa meletakkan harga bagi sesebuah projek pembinaannya. Semakan dengan REHDA Malaysia mendapati terdapat 270 buah syarikat pemaju perumahan disekitar negeri Selangor yang berdaftar dengan REHDA Malaysia. Selepas menyemak semua syarikat daripada senarai yang ada, didapati 175 buah syarikat sudah tidak beroperasi, bertukar milik dan lain-lain lagi, dan hanya tinggal 95 buah syarikat yang masih beroperasi. Daripada jumlah tersebut hanya 76 yang memberikan maklumbalas terhadap soal selidik yang diedarkan. Dapatan daripada soal selidik telah dianalisis dengan menggunakan analisis statistik deskriptif.

\section{Dapatan dan perbincangan hasil kajian}

Penelitian kajian perletakan harga rumah dalam kalangan pemaju telah diteliti menggunakan klasifikasi faktor penentu harga rumah oleh Hamzah et al. (2011). Faktor penentu perletakkan harga rumah oleh pihak pemaju telah dibahagikan kepada dua faktor iaitu faktor dalaman dan faktor luaran.

Persepsi pemaju terhadap faktor dalaman yang mempengaruhi penentuan perletakan harga rumah

Faktor dalaman merupakan faktor yang dapat dikawal sepenuhnya oleh pemilik projek (Hamzah et al., 2011). Berikut merupakan faktor dalaman yang pada pandangan pemaju berpotensi mempengaruhi perletakan harga rumah. Antaranya ialah lokasi, struktur rumah dan kemudahan infrastruktur. 


\section{i) Faktor jarak atau lokasi}

Jarak atau lokasi merupakan salah satu aspek yang mempengaruhi perletakan harga rumah. Ini adalah kerana jarak di bandar-bandar besar antara pusat bandar dan pinggir bandar dilihat mampu mempengaruhi harga (Ferlan, Bastic \& Psunder, 2017). Jadual 1 menjelaskan bahawa kedudukan projek yang berdekatan dengan kemudahan pengangkutan boleh mempengaruhi peletakan harga rumah apabila sebanyak $64.5 \%$ responden sangat setuju bahawa kemudahan pengangkutan akan mempengaruhi mereka untuk mempertimbangkan sesuatu harga perumahan. Hal ini bersesuaian dengan dapatan oleh Nizamuddin Zainuddin, Ezanee M. Elias, dan Mustakim Melan (2017), bahawa kemudahan pengangkutan mempengaruhi harga rumah. Seterusnya, penyataan rumah yang didirikan berhampiran dengan pelbagai kemudahan perniagaan juga didapati telah mempengaruhi maklumbalas pemaju terhadap peletakan harga rumah. Pemaju telah mempertimbangkan tentang perletakan sesuatu harga perumahan berdasarkan kepada kemudahan peniagaan seperti rumah kedai apabila 64.5\% sangat setuju dengan kenyataan ini.

Jadual 1. Faktor jarak atau lokasi

\begin{tabular}{|c|c|c|c|c|c|c|}
\hline Bil & Penyataan & $\begin{array}{c}\text { Sangat tidak } \\
\text { setuju }(\%)\end{array}$ & $\begin{array}{c}\text { Tidak } \\
\text { setuju } \\
(\%)\end{array}$ & $\begin{array}{c}\text { Tidak } \\
\text { pasti } \\
(\%)\end{array}$ & $\begin{array}{c}\text { Setuju } \\
(\%)\end{array}$ & $\begin{array}{l}\text { Sangat } \\
\text { setuju } \\
(\%)\end{array}$ \\
\hline 1. & $\begin{array}{l}\text { Kedudukan projek yang berdekatan } \\
\text { dengan kemudahan pengangkutan. }\end{array}$ & $\begin{array}{c}0 \\
(0)\end{array}$ & $\begin{array}{c}2 \\
(2.6)\end{array}$ & $\begin{array}{c}3 \\
(3.9)\end{array}$ & $\begin{array}{c}22 \\
(28.9)\end{array}$ & $\begin{array}{c}49 \\
(64.5)\end{array}$ \\
\hline 2. & $\begin{array}{l}\text { Rumah yang didirikan berhampiran } \\
\text { dengan pelbagai kemudahan } \\
\text { perniagaan. }\end{array}$ & $\begin{array}{c}2 \\
(2.6)\end{array}$ & $\begin{array}{c}1 \\
(1.3)\end{array}$ & $\begin{array}{c}6 \\
(7.9)\end{array}$ & $\begin{array}{c}26 \\
(34.2)\end{array}$ & $\begin{array}{c}41 \\
(53.9)\end{array}$ \\
\hline
\end{tabular}

\section{ii) Persekitaran Sosial}

Persekitaran sosial juga merupakan salah satu aspek yang mempengaruhi peletakan harga rumah.Ini adalah kerana persekitaran seperti budaya, agama, elemen kemanusiaan, alam sekitar dan lain-lain lagi turut mempengaruhi harga rumah (Stapa \& Yusuf, 2012). Jadual 2 jelas menunjukkan bahawa perumahan yang didominasi oleh sesuatu suku kaum tidak boleh mempengaruhi faktor perletakan harga rumah kerana kebanyakan responden tidak setuju dengan penyataan ini. Didapati bahawa pemaju yang memberikan maklumbalas kepada soal selidik, setuju dengan penyataan ini apabila 53.9\% (41) menyatakan lokasi yang sunyi akan mempengaruhi perletakan harga rumah manakala hanya $5.3 \%$ (4) pemaju sangat tidak setuju dengan penyataan ini. Seterusnya, kedudukan atau jarak kawasan perumahan dengan persekitaran tertentu juga mempengaruhi penentuan harga rumah. Didapati $53.9 \%$ (41) setuju dengan bahawa persekitaran tertentu mempengaruhi pertimbangan perletakan harga rumah. 
Jadual 2. Persekitaran sosial

\begin{tabular}{|c|c|c|c|c|c|c|}
\hline Bil & Penyataan & $\begin{array}{c}\text { Sangat } \\
\text { tidak } \\
\text { setuju } \\
(\%)\end{array}$ & $\begin{array}{c}\text { Tidak } \\
\text { setuju } \\
(\%)\end{array}$ & $\begin{array}{l}\text { Tidak } \\
\text { pasti } \\
(\%)\end{array}$ & $\begin{array}{l}\text { Setuju } \\
(\%)\end{array}$ & $\begin{array}{c}\text { Sangat } \\
\text { setuju } \\
(\%)\end{array}$ \\
\hline 1. & $\begin{array}{l}\text { Taman yang didominasi oleh } \\
\text { sesuatu suku kaum tidak boleh } \\
\text { mempengaruhi faktor peletakan } \\
\text { harga rumah. }\end{array}$ & $\begin{array}{c}6 \\
(7.9)\end{array}$ & $\begin{array}{c}23 \\
(30.3)\end{array}$ & $\begin{array}{c}18 \\
(23.7)\end{array}$ & $\begin{array}{c}19 \\
(25)\end{array}$ & $\begin{array}{c}10 \\
(13.2)\end{array}$ \\
\hline 2. & Lokasi perumahan yang sunyi. & $\begin{array}{c}4 \\
(5.3)\end{array}$ & $\begin{array}{c}5 \\
(6.6)\end{array}$ & $\begin{array}{c}6 \\
(7.9)\end{array}$ & $\begin{array}{c}41 \\
(53.9)\end{array}$ & $\begin{array}{c}20 \\
(26.3)\end{array}$ \\
\hline 3. & $\begin{array}{l}\text { Kedudukan perumahan dengan } \\
\text { persekitaran tertentu. }\end{array}$ & $\begin{array}{c}1 \\
(1.3)\end{array}$ & $\begin{array}{c}1 \\
(1.3)\end{array}$ & $\begin{array}{c}3 \\
(3.9) \\
\end{array}$ & $\begin{array}{c}41 \\
(53.9) \\
\end{array}$ & $\begin{array}{c}30 \\
(39.5) \\
\end{array}$ \\
\hline
\end{tabular}

iii) Reka bentuk struktur rumah

Reka bentuk struktur rumah juga ialah salah satu aspek yang juga mempengaruhi perletakan harga rumah. Reka bentuk rumah seperti keluasan ruang tamu, penyediaan bukaan seperti tingkap, bilangan tingkap dan pintu di dalam ruang tamu, lantai konkrit di halaman rumah, bumbung jejuntai, landskap, semak samun, hutan, tumbuhan rumput di halaman rumah dan cuaca boleh mempengaruhi harga rumah (Shafii, 2012). Jadual 3 menunjukkan penyataan kemasan dalaman perumahan yang berkualiti tinggi mempengaruhi harga rumah, sebanyak 50\% (38) responden sangat setuju bahawa kemasan dalaman boleh mempengaruhi perletakan harga. Ini disetujui oleh Sofyan (2017) kerana konsep perumahan SOHO yang bertemakan small office home office yang mendapat sambutan hangat terutamanya daripada bakal pembeli yang generasi yang lebih muda yang minat kepada saiz kediaman yang lebih kecil sama ada untuk tinggal atau tinggal serta bekerja. Seterusnya, untuk penyataan terhadap bilangan bilik, tandas, stor, tempat parker kenderaan juga mempengaruhi harga rumah, masing-masing memperoleh persetujuan sebanyak $46.1 \%$ (35), manakala hanya $2.6 \%$ (2) responden tidak pasti dengan penyataan ini.

Jadual 3. Reka bentuk struktur rumah

\begin{tabular}{|c|c|c|c|c|c|c|}
\hline Bil & Penyataan & $\begin{array}{c}\text { Sangat } \\
\text { tidak } \\
\text { setuju } \\
(\%)\end{array}$ & $\begin{array}{c}\text { Tidak } \\
\text { setuju } \\
(\%)\end{array}$ & $\begin{array}{c}\text { Tidak } \\
\text { pasti } \\
(\%)\end{array}$ & $\begin{array}{c}\text { Setuju } \\
(\%)\end{array}$ & $\begin{array}{c}\text { Sangat } \\
\text { setuju } \\
(\%)\end{array}$ \\
\hline 1. & $\begin{array}{l}\text { Kemasan dalaman perumahan yang } \\
\text { berkualiti tinggi. }\end{array}$ & $\begin{array}{c}0 \\
(0)\end{array}$ & $\begin{array}{c}1 \\
(1.3)\end{array}$ & $\begin{array}{c}3 \\
(3.9)\end{array}$ & $\begin{array}{c}34 \\
(44.7)\end{array}$ & $\begin{array}{c}38 \\
(50)\end{array}$ \\
\hline 2. & $\begin{array}{l}\text { Reka bentuk rumah yang moden dan } \\
\text { bertingkat. }\end{array}$ & $\begin{array}{c}0 \\
(0)\end{array}$ & $\begin{array}{c}0 \\
(0)\end{array}$ & $\begin{array}{c}8 \\
(10.5)\end{array}$ & $\begin{array}{c}40 \\
(52.6)\end{array}$ & $\begin{array}{c}28 \\
(36.8)\end{array}$ \\
\hline 3. & $\begin{array}{l}\text { Bilangan bilik, tandas, stor, tempat } \\
\text { parkir kenderaan. }\end{array}$ & $\begin{array}{c}0 \\
(0) \\
\end{array}$ & $\begin{array}{c}4 \\
(5.3) \\
\end{array}$ & $\begin{array}{c}2 \\
(2.6) \\
\end{array}$ & $\begin{array}{c}35 \\
(46.1) \\
\end{array}$ & $\begin{array}{c}35 \\
(46.1) \\
\end{array}$ \\
\hline
\end{tabular}

iv) Spekulasi perumahan

Spekulasi perumahan juga merupakan salah satu aspek yang mempengaruhi peletakan harga rumah. Berdasarkan Jadual 4 didapati bahawa kitaran harta tanah fizikal dan kitaran harta tanah modal pasaran telah mempengaruhi harga rumah dengan mendapat peratusan persetujuan paling tinggi oleh responden iaitu sebanyak 50\% (38 orang responden). Mereka setuju bahawa kitaran harta fizikal dan tanah modal pasaran mempengaruhi harga rumah manakala hanya $14.5 \%$ (11 
orang responden) responden tidak pasti dengan penyataan ini. Ini disokong oleh kajian Mariadas, Selvanathan dan Hong (2016), bahawa warganegara Malaysia suka membeli hartanah bertaraf tinggi atau high end property yang akhirnya akan menyebabkan peningkatan harga rumah. Selain itu, Mariadas, Selvanathan \& Hong (2016) turut berpendapat bahawa spekulasi positif terhadap perumahan, boleh menyebabkan kenaikan harga rumah. Hal ini jelas apabila $52.6 \%$ (40 orang responden) bersetuju bahawa potensi peningkatan harga rumah mempengaruhi harga rumah. Hal ini berkait rapat dengan penjualan semula yang mungkin dilakukan oleh pembeli pada masa hadapan. Menyedari wujudnyapeningkatan permintaan ke atas harta perumahan, maka sudah pastinya spekulasi terhadap harga berlaku melalui proses penjualan semula. Penyataan ini disokong oleh Liew \& Haron (2013) yang bersetuju bahawa penjualan semula pasti akan meningkatkan perletakan harga semasa rumah.

Pembelian rumah di kawasan bandar juga akan mempengaruhi mempengaruhi peletakan harga rumah oleh pemaju apabila sebanyak $47.4 \%$ (36) responden setuju bahawa kawasan bandar akan mempengaruhi peletakan harga rumah manakala hanya 6.6\% (5) responden tidak pasti dengan penyataan ini. Ferlan, Bastic \& Psunder (2017), menjelaskan bahawa faktor jarak dari pusat bandaraya juga mempengaruhi harga perumahan oleh pemaju. Seterusnya dalam potensi kemajuan akan datang di kawasan perumahan mempengaruhi harga rumah telah mendapat peratusan sebanyak $44.7 \%$ (34). Sebaliknya hanya $2.6 \%$ (2) responden tidak setuju dengan penyataan ini. Lu et al. (2015), menjelaskan bahawa kemajuan yang berterusan mempengaruhi harga rumah. Selain itu, penyataan pembelian rumah oleh pihak bank untuk dijual balik juga mempengaruhi harga rumah apabila sebanyak 42.1\% (32 orang responden) setuju bahawa penjualan balik oleh bank boleh mempengaruhi harga rumah.

Jadual 4. Spekulasi perumahan

\begin{tabular}{llccccc}
\hline Bil & \multicolumn{1}{c}{ Penyataan } & $\begin{array}{c}\text { Sangat } \\
\text { tidak } \\
\text { setuju } \\
(\mathbf{\%})\end{array}$ & $\begin{array}{c}\text { Tidak } \\
\text { setuju } \\
(\boldsymbol{\%})\end{array}$ & $\begin{array}{c}\text { Tidak } \\
\text { pasti } \\
(\boldsymbol{\%})\end{array}$ & $\begin{array}{c}\text { Setuju } \\
(\boldsymbol{\%})\end{array}$ & $\begin{array}{c}\text { Sangat } \\
\text { setuju } \\
(\boldsymbol{\%})\end{array}$ \\
\hline 1. & $\begin{array}{l}\text { Kitaran harta tanah fizikal dan } \\
\text { kitaran harta tanah modal pasaran. }\end{array}$ & 0 & 0 & 11 & 38 & 27 \\
2. & Potensi peningkatan harga rumah. & 1 & $(0)$ & $(14.5)$ & $(50)$ & $(35.5)$ \\
& & $(1.3)$ & $(5.3)$ & $(10.5)$ & 40 & 23 \\
3. & Pembelian rumah di kawasan & 0 & 0 & 5 & 36 & $(30.3)$ \\
& bandar. & $(0)$ & $(0)$ & $(6.6)$ & $(47.4)$ & $(46.1)$ \\
4. & $\begin{array}{l}\text { Potensi kemajuan akan datang di } \\
\text { kawasan perumahan. }\end{array}$ & 0 & 2 & 7 & 34 & 33 \\
5. & $\begin{array}{l}\text { Pembelian rumah oleh pihak bank } \\
\text { untuk dijual balik. }\end{array}$ & 1 & $(2.6)$ & $(9.2)$ & $(44.7)$ & $(43.4)$ \\
\hline
\end{tabular}

\section{v) Status fizikal rumah}

Status fizikal rumah turut mempengaruhi peletakan harga rumah. Ini adalah kerana pemaju menetapkan harga yang lebih tinggi ke atas tanah hak milik kekal berbanding hak milik bukan kekal dan rumah yang mempunyai reka bentuk khas meningkatkan harga rumah (Kamal, Hassan \& Osmadi, 2016). Jadual 5 jelas menunjukkan bahawa tanah rumah milikan Bumiputera mempengaruhi harga rumah apabila 44.7 (34) responden setuju bahawa tanah milikan Bumiputera mempengaruhi keputusan peletakan harga rumah. Seterusnya Jadual 5 menunjukkan bahawa rumah milikan Bukan Bumiputera mempengaruhi harga rumah apabila sebanyak 42.1\% 
(32) responden setuju bahawa tanah milikan Bukan Bumiputera akan mempengaruhi keputusan mereka dalam peletakan harga rumah, manakala hanya $2.6 \%$ (2) responden sangat tidak setuju sahaja. Hal ini jelas menunjukkan bahawa penyataan tanah rumah yang hak milik kekal akan mempengaruhi harga rumah apabila sebanyak $47.4 \%$ (36) responden setuju bahawa tanah rumah hak milik kekal akan diambilkira dalam peletakan harga rumah. Keadaan ini telah mempengaruhi pemaju menetapkan harga yang lebih tinggi ke atas tanah hak milik kekal berbanding bagi tanah hak milik bukan kekal (Kamal, Hassan \& Osmadi, 2016).

Jadual 5. Status fizikal rumah

\begin{tabular}{llccccc}
\hline Bil & \multicolumn{1}{c}{ Penyataan } & $\begin{array}{c}\text { Sangat } \\
\text { tidak } \\
\text { setuju } \\
(\%)\end{array}$ & $\begin{array}{c}\text { Tidak } \\
\text { setuju } \\
(\boldsymbol{\%})\end{array}$ & $\begin{array}{c}\text { Tidak } \\
\text { pasti } \\
(\%)\end{array}$ & $\begin{array}{c}\text { Setuju } \\
(\boldsymbol{\%})\end{array}$ & $\begin{array}{c}\text { Sangat } \\
\text { setuju } \\
(\%)\end{array}$ \\
\hline 1. & Tanah rumah milikan Bumiputera. & 2 & 9 & 17 & 34 & 14 \\
& & $(2.6)$ & $(11.8)$ & $(22.4)$ & $(44.7)$ & $(18.4)$ \\
2. & Tanah rumah milikan Bukan & 2 & 7 & 16 & 32 & 19 \\
& Bumiputera. & $(2.6)$ & $(9.2)$ & $(21.1)$ & $(42.1)$ & $(25)$ \\
3. & Tanah rumah yang hak milik & 0 & 2 & 6 & 36 & 32 \\
& kekal. & $(0)$ & $(2.6)$ & $(7.9)$ & $(47.4)$ & $(42.1)$ \\
4. & Tanah rumah yang hak milik & 1 & 4 & 8 & 36 & 27 \\
& bukan kekal. & $(1.3)$ & $(5.3)$ & $(10.5)$ & $(47.4)$ & $(35.5)$ \\
\hline
\end{tabular}

\section{vi) Keselamatan}

Keselamatan juga merupakan salah satu aspek yang akan mempengaruhi peletakan harga rumah. Ini adalah kerana pembeli rumah pada masa ini biasanya mahu tinggal di kawasan kejiranan dengan tempoh pegangan bebas selain kawasan kejiranan landskap yang dilindungi dan eksklusif (Tan, 2011). Jadual 6 menjelaskan bahawa pengawal keselamatan 24 jam yang sedia oleh pemaju bagi kediaman yang dibeli oleh pembeli boleh mempengaruhi harga rumah. Didapati 48.7\% (37) responden setuju bahawa kewujudan pengawal keselamatan akan diambilkira dalam mempengaruhi peletakan harga rumah. Sebaliknya hanya $1.3 \%$ (1) responden sangat tidak setuju dengan penyataan ini. Ini adalah kerana perkhidmatan keselamatan di kawasan perumahan seperti rumah yang mempunyai pegawai keselamatan merupakan perkara yang perlu dipertimbangkan oleh kebanyakan pembeli rumah. Ini disokong oleh Osmadi et al. (2015) yang mendapati bahawa keselamatan begitu diberikan perhatian oleh pembeli dalam konteks jaminan kesejahteraan mereka.

Perkara ini sangat jelas menunjukkan bahawa penyataan sistem sekuriti yang berteknologi tinggi dan canggih akan mempengaruhi harga rumah apabila 52.6\% (40) responden setuju dalam penyataan ini bahawa sistem sekuriti akan dipertimbangan semasa peletakan harga rumah manakala hanya 1.3\% (1) responden sangat tidak setuju dengan penyataan ini. Ini disokong oleh kajian Osmadi et al. (2015) kerana untuk memenuhi permintaan pembeli rumah yang semakin tinggi dalam keperluan keselamatan. Selain itu keperluan terhadap sistem perlindungan kebakaran yang baik juga turut mempengaruhi harga rumah. Hal ini disetujui oleh kebanyakan responden apabila $44.7 \%$ (34) menjelaskan bahawa sistem perlindungan akan dipertimbangkan semasa peletakan harga rumah. Sebaliknya, hanya $2.6 \%$ (2) sangat tidak setuju dengan penyataan ini. 
Jadual 6. Faktor keselamatan

\begin{tabular}{|c|c|c|c|c|c|c|}
\hline Bil & Penyataan & $\begin{array}{c}\text { Sangat } \\
\text { tidak } \\
\text { setuju } \\
(\%)\end{array}$ & $\begin{array}{c}\text { Tidak } \\
\text { setuju } \\
(\%)\end{array}$ & $\begin{array}{c}\text { Tidak } \\
\text { pasti } \\
(\%)\end{array}$ & $\begin{array}{c}\text { Setuju } \\
(\%)\end{array}$ & $\begin{array}{c}\text { Sangat } \\
\text { setuju } \\
(\%)\end{array}$ \\
\hline 1. & $\begin{array}{l}\text { Pengawal keselamatan } 24 \text { jam } \\
\text { yang sedia. }\end{array}$ & $\begin{array}{c}1 \\
(1.3)\end{array}$ & $\begin{array}{c}4 \\
(5.3)\end{array}$ & $\begin{array}{c}9 \\
(11.8)\end{array}$ & $\begin{array}{c}37 \\
(48.7)\end{array}$ & $\begin{array}{c}25 \\
(32.9)\end{array}$ \\
\hline 2. & $\begin{array}{l}\text { Sistem sekuriti yang berteknologi } \\
\text { tinggi dan canggih. }\end{array}$ & $\begin{array}{c}0 \\
(0)\end{array}$ & $\begin{array}{c}1 \\
(1.3)\end{array}$ & $\begin{array}{c}6 \\
(7.9)\end{array}$ & $\begin{array}{c}40 \\
(52.6)\end{array}$ & $\begin{array}{c}29 \\
(38.2)\end{array}$ \\
\hline 3. & $\begin{array}{l}\text { Sistem perlindungan kebakaran } \\
\text { yang baik. }\end{array}$ & $\begin{array}{c}0 \\
(0)\end{array}$ & $\begin{array}{c}2 \\
(2.6)\end{array}$ & $\begin{array}{l}19 \\
(25)\end{array}$ & $\begin{array}{c}34 \\
(44.7)\end{array}$ & $\begin{array}{c}21 \\
(27.6)\end{array}$ \\
\hline
\end{tabular}

\section{Faktor luaran yang mempengaruhi penentu harga rumah}

Faktor luaran ialah faktor yang dapat tidak dapat dikawal sepenuhnya seperti kos bahan binaan, kos penggunaan bahan lestari, jentera dan sebagainya oleh pemilik kontrak. Berikut adalah faktor luaran yang berpotensi mempengaruhi harga rumah. Antaranya ialah kadar pinjaman, penggunaa teknologi hijau, penggunaan bahan mesra alam dan cukai perumahan.

\section{i) Kadar pinjaman}

Kadar pinjaman merupakan merupakan salah satu aspek yang akan mempengaruhi peletakan harga rumah. Ini adalah kerana semakin tinggi kadar pinjaman, semakin tingginya kos pembiayaan dan modal untuk digunakan dalam projek pembinaan rumah (Guo \& Wu, 2013). Jadual 7, menunjukkan bahawa kadar pulangan pinjaman boleh mempengaruhi harga rumah, analisis mendapati sebanyak 39.5\% (30) responden setuju bahawa kadar pulangan pinjaman akan mempengaruhi peletakan harga rumah manakala hanya $2.6 \%$ (2) responden sangat tidak setuju dengan penyataan ini. Selain itu, penyataan penarikan subsidi terhadap perumahan juga boleh mempengaruhi harga rumah dengan peratusan sebanyak $51.3 \%$ (39) responden bersetuju dengan kenyataan tersebut. Dapatan temubual dengan pemaju mendapati penarikan subsidi terhadap bahan binaan boleh meningkatkan kos pembinaan perumahan. Di samping itu untuk penyataan keluaran dalam negeri kasar (GDP) akan mempengaruhi harga rumah dengan $40.8 \%$ (31 orang responden) setuju bahawa GDP akan diambil kira dalam penentuan harga rumah. Ini adalah kerana ia didorong oleh permintaan isi rumah yang semakin tinggi, dengan pertumbuhan tahunan yang luar biasa dalam kedua-dua perbelanjaan pelaburan swasta dan awam. Ini disokong oleh Liew \& Haron (2013), yang menyatakan bahawa permintaan isi rumah akan mempengaruhi peletakan harga rumah. Ini kerana sebahagian besar daripada responden iaitu hampir 56\% (42) telah berjaya mendapatkan pembiayaan melalui pihak bank. 
Jadual 7. Kadar pinjaman

\begin{tabular}{|c|c|c|c|c|c|c|}
\hline Bil & Penyataan & $\begin{array}{c}\text { Sangat } \\
\text { tidak } \\
\text { setuju } \\
(\%) \\
\end{array}$ & $\begin{array}{l}\text { Tidak } \\
\text { setuju } \\
(\%)\end{array}$ & $\begin{array}{l}\text { Tidak } \\
\text { pasti } \\
(\%)\end{array}$ & $\begin{array}{c}\text { Setuju } \\
(\%)\end{array}$ & $\begin{array}{c}\text { Sangat } \\
\text { setuju } \\
(\%)\end{array}$ \\
\hline 1. & Kadar pulangan pinjaman. & $\begin{array}{c}2 \\
(2.6)\end{array}$ & $\begin{array}{c}5 \\
(6.6)\end{array}$ & $\begin{array}{c}21 \\
(27.6)\end{array}$ & $\begin{array}{c}30 \\
(39.5)\end{array}$ & $\begin{array}{c}18 \\
(23.7)\end{array}$ \\
\hline 2. & $\begin{array}{l}\text { Pinjaman yang disediakan oleh } \\
\text { pihak swasta, bank, kerajaan, } \\
\text { rakan kongsi. }\end{array}$ & $\begin{array}{c}2 \\
(2.6)\end{array}$ & $\begin{array}{c}10 \\
(13.2)\end{array}$ & $\begin{array}{c}18 \\
(23.7)\end{array}$ & $\begin{array}{c}30 \\
(39.5)\end{array}$ & $\begin{array}{c}16 \\
(21.1)\end{array}$ \\
\hline 3. & $\begin{array}{l}\text { Penarikan } \\
\text { perumahan. }\end{array}$ & $\begin{array}{c}1 \\
(1.3)\end{array}$ & $\begin{array}{c}1 \\
(1.3)\end{array}$ & $\begin{array}{c}15 \\
(19.7)\end{array}$ & $\begin{array}{c}39 \\
(51.3)\end{array}$ & $\begin{array}{c}20 \\
(26.3)\end{array}$ \\
\hline 4. & $\begin{array}{l}\text { Keluaran dalam negeri kasar } \\
\text { (GDP). }\end{array}$ & $\begin{array}{c}2 \\
(2.6)\end{array}$ & $\begin{array}{c}5 \\
(6.6) \\
\end{array}$ & $\begin{array}{c}25 \\
(32.9)\end{array}$ & $\begin{array}{c}31 \\
(40.8) \\
\end{array}$ & $\begin{array}{c}13 \\
(17.1)\end{array}$ \\
\hline
\end{tabular}

\section{viii) Penggunaan teknologi hijau}

Penggunaan teknologi hijau juga merupakan salah satu aspek yang akan mempengaruhi peletakan harga rumah. Ini adalah kerana teknologi hijau juga semakin berkembang dan memberi kesan yang tinggi kepada kos (Hassan, Salamon \& Rahman, 2017). Analisis daripada Jadual 8 untuk penyataan teknologi baharu, terkini atau canggih didapati telah mendapat respon daripada responden bahawa harga rumah juga dipengaruhi oleh penggunaan teknologi oleh pihak pemaju. Didapati hampir 48\% (36) daripada responden setuju dengan penyataan ini. Seterusnya konsep perumahan dalam taman juga mempengaruhi perletakkan harga rumah oleh pemaju. Analisis mendapati hampir 48\% (36) responden setuju bahawa konsep perumahan akan mempengaruhi harga rumah. Ini disokong oleh Ashrai \& Bakar (2017) kerana konsep perumahan mampan tidak boleh meminggirkan masalah-masalah ini dalam mereka bentuk rumah dan kawasan kejiranan. Selain itu, untuk penyataan penggunaan mesin yang mesra alam dalam pembinaan akan mempengaruhi harga rumah, sebanyak 32.9\% (25) responden setuju bahawa mesin yang mesra alam akan mempengaruhi peletakan harga rumah. Ini adalah kerana penggunaan jentera melibatkan kos dan modal yang sangat tinggi (Mohamed Nor Azhari Azmana et al., 2016).

Di samping itu, untuk penyataan pelupusan bahan buangan binaan secara teratur akan mempengaruhi harga rumah, sebanyak $36.8 \%$ (28) responden setuju bahawa pembuangan secara teratur akan diambil kira dalam peletakan harga rumah manakala hanya $5.3 \%$ (4) responden sangat tidak setuju dengan penyataan ini. Ini adalah kerana pengurusan sisa buangan secara bersistematik akan melibatkan pertambahan kos projek dan secara tidak langsung akan mengurangkan keuntungan yang bakal diperolehi oleh pihak pemaju perumahan. Penyataan ini disetujui oleh Wee, Halim \& Mohamad (2006) kerana pembuangan secara teratur akan melibatkan kos yang sangat tinggi. Justeru itu, untuk penyataan penekanan kepada konsep tertentu yang berkaitan dengan teknologi hijau akan mempengaruhi harga rumah, sebanyak $56.6 \%$ (43) responden setuju bahawa penekanan kepada konsep akan mempengaruhi penetapan harga. Sebaliknya hanya $5.3 \%$ (4) responden tidak setuju dengan penyataan ini. Ini disokong oleh Tighe (2012) kerana masalah perumahan kurang mampan sering dianggap berlaku ke atas perumahan mampu milik. 
Jadual 8. Penggunaan teknologi hijau

\begin{tabular}{|c|c|c|c|c|c|c|}
\hline Bil & Penyataan & $\begin{array}{c}\text { Sangat } \\
\text { tidak } \\
\text { setuju } \\
(\%) \\
\end{array}$ & $\begin{array}{c}\text { Tidak } \\
\text { setuju } \\
(\%)\end{array}$ & $\begin{array}{c}\text { Tidak } \\
\text { pasti } \\
(\%)\end{array}$ & $\begin{array}{c}\text { Setuju } \\
(\%)\end{array}$ & $\begin{array}{c}\text { Sangat } \\
\text { setuju } \\
(\%)\end{array}$ \\
\hline 1. & Teknologi baharu/terkini/canggih. & $\begin{array}{c}1 \\
(1.3)\end{array}$ & $\begin{array}{c}3 \\
(3.9)\end{array}$ & $\begin{array}{c}10 \\
(13.2)\end{array}$ & $\begin{array}{c}36 \\
(47.4)\end{array}$ & $\begin{array}{c}26 \\
(34.2)\end{array}$ \\
\hline 2. & Konsep perumahan dalam taman. & $\begin{array}{c}1 \\
(1.3)\end{array}$ & $\begin{array}{c}3 \\
(3.9)\end{array}$ & $\begin{array}{c}7 \\
(9.2)\end{array}$ & $\begin{array}{c}36 \\
(47.4)\end{array}$ & $\begin{array}{c}29 \\
(38.2)\end{array}$ \\
\hline 3. & $\begin{array}{l}\text { Penggunaan mesin yang mesra } \\
\text { alam dalam pembinaan. }\end{array}$ & $\begin{array}{c}2 \\
(2.6)\end{array}$ & $\begin{array}{c}7 \\
(9.2)\end{array}$ & $\begin{array}{c}18 \\
(23.7)\end{array}$ & $\begin{array}{c}25 \\
(32.9)\end{array}$ & $\begin{array}{c}24 \\
(31.6)\end{array}$ \\
\hline 4. & $\begin{array}{l}\text { Perlupusan bahan buangan binaan } \\
\text { secara teratur. }\end{array}$ & $\begin{array}{c}4 \\
(5.3)\end{array}$ & $\begin{array}{c}13 \\
(17.1)\end{array}$ & $\begin{array}{c}20 \\
(26.3)\end{array}$ & $\begin{array}{c}28 \\
(36.8)\end{array}$ & $\begin{array}{c}11 \\
(14.5)\end{array}$ \\
\hline 5. & $\begin{array}{l}\text { Penekanan kepada konsep tertentu } \\
\text { yang berkaitan dengan teknologi } \\
\text { hijau. }\end{array}$ & $\begin{array}{c}0 \\
(0)\end{array}$ & $\begin{array}{c}4 \\
(5.3)\end{array}$ & $\begin{array}{c}16 \\
(21.1)\end{array}$ & $\begin{array}{c}43 \\
(56.6)\end{array}$ & $\begin{array}{c}13 \\
(17.1)\end{array}$ \\
\hline
\end{tabular}

viiii) Penggunaan bahan mesra alam

Penggunaan bahan mesra alam juga merupakan salah satu aspek yang akan mempengaruhi peletakan harga rumah. Ini adalah kerana kualiti bahan binaan dan tahap penambahbaikan struktur yang dibuat kepada perumahan juga boleh menjadi faktor penting dalam menentukan nilai rumah (Musa, Zahari \& Yusoff, 2009). Jadual 9 menunjukkan majoriti responden iaitu hampir 49\% (37 orang) setuju dengan penyataan penggunaan bahan binaan yang mesra alam akan mempengaruhi perletakkan harga rumah. Ini kerana penggunaan bahan yang mesra alam akan mempengaruhi peletakan harga rumah kerana penggunaan bahan binaan yang mesra alam akan meningkatkan kos pembinaan dan mengurangkan keuntungan. Selain itu hampir 40\% (30 orang) responden setuju dengan penyataan penggunaan bahan kitar semula dalam pembinaan akan mempengaruhi harga rumah. Penggunaan bahan kitar semula akan diambil kira dalam peletakan harga rumah.

Jadual 9. Penggunaan bahan mesra alam

\begin{tabular}{|c|c|c|c|c|c|c|}
\hline Bil & Penyataan & $\begin{array}{c}\text { Sangat } \\
\text { tidak } \\
\text { setuju } \\
(\%)\end{array}$ & $\begin{array}{c}\text { Tidak } \\
\text { setuju } \\
(\%)\end{array}$ & $\begin{array}{c}\text { Tidak } \\
\text { pasti } \\
(\%)\end{array}$ & $\begin{array}{c}\text { Setuju } \\
(\%)\end{array}$ & $\begin{array}{c}\text { Sangat } \\
\text { setuju } \\
(\%)\end{array}$ \\
\hline 1. & $\begin{array}{l}\text { Penggunaan bahan binaan yang } \\
\text { mesra alam. }\end{array}$ & $\begin{array}{c}0 \\
(0)\end{array}$ & $\begin{array}{c}6 \\
(7.9)\end{array}$ & $\begin{array}{c}17 \\
(22.4)\end{array}$ & $\begin{array}{c}37 \\
(48.7)\end{array}$ & $\begin{array}{c}16 \\
(21.1)\end{array}$ \\
\hline 2. & $\begin{array}{l}\text { Penggunaan bahan kitar semula } \\
\text { dalam pembinaan. }\end{array}$ & $\begin{array}{c}2 \\
(2.6)\end{array}$ & $\begin{array}{c}8 \\
(10.5)\end{array}$ & $\begin{array}{c}22 \\
(28.9)\end{array}$ & $\begin{array}{c}30 \\
(39.5)\end{array}$ & $\begin{array}{c}14 \\
(18.4)\end{array}$ \\
\hline
\end{tabular}

\section{x) Cukai perumahan}

Cukai perumahan juga merupakan salah satu aspek yang akan mempengaruhi peletakan harga rumah. Ini adalah kerana kerajaan telah meningkatkan cukai keuntungan harta sebanyak 5\% hingga $15 \%$ untuk urus niaga jangka pendek antara pembeli rumah kali pertama untuk mengawal masalah kenaikan harga rumah (Liew \& Haron, 2013). Pemaju akan meletakkan harga rumah bergantung kepada cukai pembinaan. Jadual 10 menunjukkan sebanyak 44.7\% (34 orang) responden setuju dengan penyataan cukai pembinaan perumahan yang dikenakan terhadap 
pemaju akan mempengaruhi harga rumah. Sebaliknya hanya 2.6\% (2 orang) tidak setuju dengan penyataan ini.

Selain itu, pemaju juga akan meletakkan harga dengan melihat penyataan kontrak pembinaan. Didapati hampir 37\% (28 orang) responden setuju dengan penyataan kontrak pembinaan yang dikenakan terhadap pemaju akan mempengaruhi harga rumah manakala hanya 9.2\% (7orang) responden tidak setuju dengan penyataan ini. Di samping itu, cukai taksiran juga akan dipertimbangkan semasa peletakan harga rumah kerana sebanyak 44.7\% (34) responden setuju dengan penyataan cukai taksiran yang dikenakan terhadap pemaju boleh mempengaruhi harga rumah. Sebaliknya, hanya $1.3 \%$ (1) responden sangat tidak setuju dengan penyataan ini. Ini kerana cukai taksiran yang dikenakan sebanyak 2 kali setahun terpaksa dibayar oleh pihak pemaju walaupun rumah itu kosong atau tidak didiami. Oleh itu perkara ini amat mempengaruhi peletakan harga rumah. Di samping itu, bagi pemaju cukai jualanan juga boleh mempengaruhi kenaikan harga rumah. Analisis mendapati 51.3\% (39 orang) responden setuju dengan penyataan cukai jualanan yang dikenakan terhadap pemaju akan mempengaruhi harga rumah manakala hanya $1.3 \%$ (1) responden sahaja sangat tidak setuju dengan penyataan ini. Ini adalah kerana sebarang keuntungan yang timbul daripada pelupusan hartanah dalam tempoh 5 tahun akan dikenakan cukai sebanyak 5\% (San Ong, 2013).

Tambahan itu, pemaju juga akan mengambil kira cukai tanah semasa meletakkan harga rumah apabila sebanyak 40.8\% (31) responden setuju dengan penyataan cukai tanah oleh kerajaan yang dikenakan terhadap pemaju akan mempengaruhi harga rumah manakala hanya 9.2\% (7) responden tidak setuju dengan penyataan ini. Selain itu, cukai keuntungan juga dipertimbangkan oleh pemaju semasa peletakan harga sesebuah unit kediaman, apabila sebanyak $39.5 \%$ (30) responden setuju dengan penyataan cukai keuntungan harta tanah (CKHT) yang dikenakan terhadap pemaju akan mempengaruhi harga rumah.

Jadual 10. Cukai perumahan

\begin{tabular}{llccccc}
\hline Bil & \multicolumn{1}{c}{ Penyataan } & $\begin{array}{c}\text { Sangat } \\
\text { tidak } \\
\text { setuju } \\
(\mathbf{\%})\end{array}$ & $\begin{array}{c}\text { Tidak } \\
\text { setuju } \\
(\mathbf{\%})\end{array}$ & $\begin{array}{c}\text { Tidak } \\
\text { pasti } \\
(\boldsymbol{\%})\end{array}$ & $\begin{array}{c}\text { Setuju } \\
(\boldsymbol{\%})\end{array}$ & $\begin{array}{c}\text { Sangat } \\
\text { setuju } \\
(\boldsymbol{\%})\end{array}$ \\
\hline 1. & Cukai pembinaan perumahan yang & 0 & 2 & 10 & 34 & 30 \\
& dikenakan terhadap pemaju. & $(0)$ & $(2.6)$ & $(13.2)$ & $(44.7)$ & $(39.5)$ \\
2. & Kontrak pembinaan yang & 0 & 7 & 19 & 28 & 22 \\
& dikenakan terhadap pemaju. & $(0)$ & $(9.2)$ & $(25)$ & $(36.8)$ & $(28.9)$ \\
3. & Cukai pinjaman perumahan yang & 0 & 3 & 15 & 35 & 23 \\
& dikenakan terhadap pemaju. & $(0)$ & $(3.9)$ & $(19.7)$ & $(46.1)$ & $(30.3)$ \\
4. & Cukai taksiran yang dikenakan & 1 & 4 & 18 & 34 & 19 \\
& terhadap pemaju. & $(1.3)$ & $(5.3)$ & $(23.7)$ & $(44.7)$ & $(25)$ \\
5. & Cukai jualanan yang dikenakan & 1 & 3 & 13 & 39 & 20 \\
& terhadap pemaju. & $(1.3)$ & $(3.9)$ & $(17.1)$ & $(51.3)$ & $(26.3)$ \\
6. & Cukai tanah oleh kerajaan yang & 0 & 7 & 12 & 31 & 26 \\
& dikenakan terhadap pemaju. & $(0)$ & $(9.2)$ & $(15.8)$ & $(40.8)$ & $(34.2)$ \\
7. & Cukai keuntungan harta tanah & 1 & 6 & 14 & 30 & 25 \\
& (CKHT) yang dikenakan terhadap & $(1.3)$ & $(7.9)$ & $(18.4)$ & $(39.5)$ & $(32.9)$ \\
& pemaju. & & & & & \\
\hline
\end{tabular}




\section{Kesimpulan}

Secara keseluruhannya terdapat dua faktor yang mempengaruhi peletakan harga rumah dalam kalangan pemaju iaitu faktor dalaman dan faktor luaran. Dapatan daripada analisis yang dilakukan mendapati bahawa pemaju perumahan di kawasan kajian cenderung untuk menggunakan faktor dalaman sebagai faktor utama dalam mempertimbangkan peletakan harga rumah. Antara faktor yang sangat mempengaruhi pertimbangan peletakan harga dalam kalangan pemaju adalah ciri-ciri struktur rumah. Dalam hal ini, bentuk, konsep dan keluasan binaan rumah telah memberi impak yang besar terhadap perletakan harga rumah. Selain itu jarak dan lokasi juga merupakan antara faktor penting terhadap nilai perletakan harga unit kediaman yang dibina oleh pihak pemaju.

Oleh itu, bagi membendung masalah kenaikan harga rumah yang sukar dibendung, pihak kerajaan perlu memberi penekanan terhadap kemampuan pengguna untuk membeli pada kadar harga yang tertentu. Dalam hal ini, pihak kerajaan boleh meletakkan harga siling pada jenis-jenis struktur rumah tertentu. Hal ini perlu bagi memastikan unit-unit yang dibina dapat memenuhi keperluan permintaan dan kemampuan pembeli. Dalam masa yang sama, masalah kenaikan kos harga rumah yang sukar dikawal akan dapat dibendung. Selain itu, pihak pemaju juga boleh berkerjasama dengan pihak kerajaan untuk menyemak balik polisi pinjaman yang dikenakan kepada pengguna. Menerusi semakan semula polisi pinjaman juga, pihak pemaju perumahan juga boleh meminjam wang daripada pihak bank dengan kadar bunga yang rendah. Maka kos pembinaan akan menjadi lebih murah dan harga rumah akan menurun. Selain itu keperluan untuk menyemak balik kadar cukai yang dikenakan. Pihak pemaju boleh mencadangkan agar cukai seperti cukai perumahan yang dikenakan sebanyak 6\% dihapuskan agar kos pembinaan akan lebih murah. Ini kerana apabila cukai perumahan dikawal, sudah pasti implikasinya harga rumah turut dapat dibendung daripada terus meningkat.

\section{Rujukan}

Abraham, J.M., \& Hendershoti, P.H. (2014). Bubbles in metropolitan housing market. Housing Markets. Utusan Malaysia.

Auyong, H.N., Yip, C.Y., Woo, K.H., \& Senadjki, A. (2018). The dynamics of housing prices in Malaysia: findings from focus group discussions. MATEC Web of Conference 05088, 1-5.

Dziauddin, F. (1985). The determinants of house prices in the Klang Valley, Malaysia. Jurnal Perspektif, 1, 70-80.

Engle, R.F., Lilien, D.M., \& Watson, M. (1985). A dynamic model of housing price determination. Journal of Econometrics, 28(3), 307-326.

Ferlan, N., Bastic, M., \& Psunder, I. (2017). Influential factors on the market value of residential properties. Inzinerine Ekonomika-Engineering Economics, 28(2), 135-144.

Kok, S.H., Ismail, N.W., \& Lee, C. (2018). The sources of house price changes in Malaysia. International Journal of Housing Markets and Analysis, 11(2), 335-355.

Kamal, E.M., Hassan, H., \& Osmadi, A. (2016). Factors influencing the housing price: developers' perspective, International Journal of Humanities and Social Sciences, 10(5), 1676-1682.

Husain, F., Rahman, R., \& Ibrahim, N. (2011). Housing bubbles assessment in Klang Valley, 2005-2010. Faculty of Business Management, 4(1), 561-574. 
Hassan, N., Salamon, H., \& Rahman, H.A. (2017). Peranan aplikasi teknologi hijau dalam konteks melestarikan Alam Sekitar Menurut Perspektif Islam. Jurnal Penyelidikan dan Inovasi, 3(2), 14-24

Liew, C., \& Haron, N.A. (2013). Factors influencing the rise of house price in Klang. International Journal of Research in Engineering and Technology, 261-272.

Lu, L.Y., Lee, J.Y. M., Al-mulali, U., Ahmad, N.A., \& Mohammad, I.S. (2015). Housing bubble in Penang: Prediction and determinants. Jurnal Teknologi, 5, 65-69.

Laporan Pasaran Harta (2018). Jabatan Penilaian dan Perkhidmatan Harta. Kementerian Kewangan Malaysia.

Musa, U., Zahari, W., \& Yusoff, W. (2009). The influence of housing components on prices of residential houses: A review of literature. The Social Sciences, 12(4), 625-632.

Mints, V. (2008). Factors affecting housing price trends in Russia. Problems of Economic Transition, 50(10), 30-43.

Mariadas, P.A., Selvanathan, M., \& Hong, T.K. (2016). A study on housing price in Klang Valley, Malaysia. International Business Research, 9(12), 103-113.

Hamzah. N.A, Khoiry M.A, Ali M.A., Zaini, N.S., \& Arshad, I. (2011). Faktor luaran dan dalaman yang mempengaruhi harga rumah teres di Bandar Baru Bangi. Jurnal Rekabentuk dan Binaan, 4, 1-8.

Nizamuddin Zainuddin, Ezanee M.E., \& Mustakim Melan, R.S. (2017). Aplikasi teknologi kelestarian (hybrid) pada pengangkutan awam (bas) di bandar: Satu pendekatan diskriptif. Journal of Technology and Operations Management, (S), 71-87.

Osmadi, A., Kamal, E.M., Hassan, H., \& Fattah, H.A. (2015). Exploring the elements of housing price in Malaysia. Asian Social Science, 11(24), 26-38.

Raden Aswin Rahadi, S.D. (2015). Factors influencing the price of housing in Indonesia. School of Business and Management, Institut Teknologi Bandung 8(1):12-22.

Rizanizam Abdul. (2018). SST: Harga rumah boleh turun hingga 10 peratus. BH Online, 12 Ogos 2018.

Rahimah Abdullah. (2018). Tarik balik pengecualian SST kalau harga rumah tak turun-Guan Eng, Astro Awani, 24 Sept 2018.

Stapa, Z., Ahmad Munawar I., \& Noranizah, Y. (2012). Faktor persekitaran sosial dan hubungannya dengan pembentukan jati diri. Jurnal Hadhari: An International Journal, (S), 155-172.

Shafii, H. (2012). Keselesaan terma rumah kediaman dan pengaruhnya terhadap kualiti hidup penduduk. Geografia-Malaysian Journal of Society and Space, 4(4), 28-43.

Sorina, V. (2014). Identifying factors impacting property values. The Bucharest University of Economic Studies.

Wee, S.T., Halim, A., \& Mohamad, B. (2006). Pengurusan sisa pembinaan di tapak bina. Universiti Tun Hussein Onn Malaysia, Johor. 